\title{
'The Court is Accommodating our Murderers': Prosecuting Aged Defendants in Domestic Courts in Bosnia and Herzegovina
}

\author{
Hikmet Karcic | ORCID: oooo-ooo2-2361-692X \\ Department of Humanities, University of Groningen, Hoendiepskade \\ 23-24, 9718 BG Groningen, The Netherlands \\ karcichikmet@gmail.com
}

\begin{abstract}
Although the war in Bosnia and Herzegovina ended a quarter of a century ago, a large number of war crimes suspects are still being prosecuted. One of the visible issues arising in domestic courts are aged defendants, whose trials are delayed due to old age and illness. The aim of this article is to give an overview of case law and analyze the process of prosecuting aged defendants at the War Crimes Chamber within the Court of Bosnia and Herzegovina, which carries the largest workload of war crimes cases in the region. This article focuses on two main aspects: portrayal of these cases in the media and the legal reasoning of the court.
\end{abstract}

\section{Keywords}

aged defendants - war criminals - Bosnia and Herzegovina - mass atrocities - media - law

\section{Introduction}

In September 2020, a rather intriguing press release was published by Bosnia and Herzegovina's Chief Prosecutor. It stated that 76-year-old Ratko Đurković had been arrested in Ugljevik, in north-eastern Bosnia and Herzegovina ( $\mathrm{BiH})$. He had served as commander of the Bosnian Serb Army in the Majevica 
Brigade First Battalion. Đurković, along with the Brigade commander, the now 76-year-old Radomir Nedić, were charged with crimes against humanity and crimes against prisoners of war against Bosniaks in July 1992. The strange part of this press release was that Nedić, although located, had not been arrested. It stated: 'In relation to the suspect Nedić, the case prosecutor will, after collecting all the information and data on his health condition, decide on further activities with regard to the suspect.' 1

The first thought which arose from this report was: why did the authorities even attempt to arrest a suspect who was not in a condition to be arrested? And if he was in no condition to be arrested, how is it expected for him to stand trial?

The President of the Veterans Association in Ugljevik strongly protested the arrest, stating that: 'We condemn the arrest of our comrade-in-arms, especially in such a disgusting way, by coming to the family home early in the morning and scaring his family members. This is an elderly person, who is 76 years old.'

In the meantime, the Sarajevo-based news website Faktor.ba published a short commentary titled 'Artuković was once Extradited from the USA on a Stretcher, and Today BiH Accepts the "Medical Justification" of the Suspects' ${ }^{3}$ The commentary criticized the authorities and compared the treatment of Nedić, with the infamous Ustaša official Andrija Artuković. Artuković, a minister in the Nazi-puppet Independent State of Croatia, was extradited to Yugoslavia by the United States of America in 1984. It argued that although Artuković was diagnosed with Parkinson's and Alzheimer's disease, he was brought on crutches and faced trial. If Artuković was still deemed fit to be tried, then Nedić definitely was.

Đurković's arrest created a broader reaction however. His arrest was called '[a]n inappropriate act, a blow to an honorable and honest man, who has

1 'On Order of Prosecutor of Special Department for War Crimes of Prosecutor's Office of BiH One Person Deprived of Liberty', Prosecutor's Office of Bosnia and Herzegovina (8 September 2020), available online at www.tuzilastvobih.gov.ba/index.php?id=4591\&jezik=e (accessed 28 February 2021).

2 'U Ugljeviku uhapšen major bivše Vojske Rs osumnjičen za ratne zločine', Danas (8 September 2020), available online at www.danas.rs/svet/u-ugljeviku-uhapsen-major-bivse-vojske-rsosumnjicen-za-ratne-zlocine/ (accessed 10 March 2021).

3 A. Dr. 'Artukovića su nekada na nosilima izručivali iz SAD-a, a BiH danas prihvata "ljekarsko opravdanje" osumnjičenih', Faktor.ba (8 September 2020), available online at www.faktor.ba/ vijest/artukovica-su-nekada-na-nosilima-izrucivali-iz-sad-a-a-bih-danas-prihvata-ljekarskoopravdanje-osumnjicenih/96842 (accessed 8 March 2021). 
never stepped on an ant in his life, and he has been and remains a sworn anti-fascist. ${ }^{4,5}$

Đurković himself is an example of interconnected time zones, ideologies, wars and life cycles. Born in World War Two, educated and raised in Communist Yugoslavia, he took an active role in the 1992-1995 Bosnian war, commanded a brigade and continued his pre-war life, as an "anti-fascist" after the conflict ended. Neither he nor Nedić were publicly well-known, they are not in the same league as those infamous untouchables like Rogatica brigade commander Rajko Kušić ${ }^{6}$ or Čajnice Crisis Committee President, Duško Kornjača. ${ }^{7}$ If they had not been indicted, they probably would never have been publicly recognizable.

The war in BiH ended a quarter of a century ago, and a large number of the perpetrators have been prosecuted, although a significant number still remain 'untouchable'. The issue of the age of defendants is yet to be addressed in the country's courts. There has been no major research done on this issue. The reason for this probably is that there have not been many such cases yet. This article will attempt to draw an outline of known existing cases, shedding light on the issue of prosecuting aged defendants, in front of the national courts in Bosnia and Herzegovina. This article focuses on two aspects: portrayal of these cases in the media and the case law of the courts. This research will focus on the cases in front of the War Crimes Chamber within the state Court of Bosnia and Herzegovina, which carries the largest workload of war crimes cases in the region.

The State Court of Bosnia and Herzegovina was formed in 2003. A special War Crime Chamber was established within the court to deal with war crimes. The

4 O. M. - V. M., 'Zbog sumnje da je umešan u ratne zločine: uhapšen Ratko Đurković, komandant majevičke brigade', Novosti.rs (8 September 2020), available online at www.novosti.rs/ republika-srpska/vesti/915766/zbog-sumnje-umesan-ratne-zlocine-uhapsen-ratko-djurkovickomandant-majevicke-brigade (accessed 7 March 2021).

5 He was a member of the Socialist Party and president of the Alliance of Associations of Veterans of the People's Liberation War (SUBNOR) in Ugljevik. SUBNOR is a World War Two veterans associations gathering former partisans and an influential pillar in Communist Yugoslavia.

6 Court of Bosnia and Herzegovina, Indictment confirmed in the Rajko Kušić case (3 April 2015), available online at www.sudbih.gov.ba/vijest/potvrena-optunica-u-predmetu-rajko-kui-19903 (accessed 28 February 2021).

7 Court of Bosnia and Herzegovina, Prosecutor's Office of Bosnia and Herzegovina v. Kornjača Duško, Case no.:Sı 1 K oo2648 15 Kro, available online at www.sudbih.gov.ba/predmet/3567/ show (accessed 28 February 2021). 
Chamber was composed of a mix of local and foreign staff, including prosecutors and judges. The aim was to take over several cases from the ICTY and slowly start independently prosecuting individuals. This hybrid status of the court was never meant to be permanent, but rather temporary until the conditions for a steady transfer to entirely local staff could be made. The foreign staff eventually left the court in $2012 .^{8}$

Some argue the presence of foreign staff enhanced the quality of the prosecution of cases and that the total domestic take-over of the court made it more vulnerable to influence from political actors in the country. Recent export reports have shown that the work of the War Crime Chamber has been stagnating in the past decade. Prosecutors have issued a minimum of indictments, based mainly on poor investigations, out of which a significant number have failed. ${ }^{9}$

Noticeably, certain high-ranking officials who sit in public office, have not been investigated for war crimes although evidence exists against them, whilst in other cases even when indictments are issued, defense councils manage to prolong the cases Šešelj-style until exhaustion. In most cases, old age and health issues are used to justify a trial extension.

In 2010, the BiH Prosecutor's Office reported approximately that it had 1381 war-crimes case files, related to some 8249 suspects, which is half the 2007 estimate of 13 ooo to 17 Ooo perpetrators. ${ }^{10}$ In an 2018 OSCE report, it was found that only $70 \%$ of the 800 'Category A' cases (cases reviewed by the ICTY отP as an 'independent oversight mechanism') have been processed by the domestic courts. ${ }^{11}$ As noted by Judge Joanna Korner in her report, given the length of the trials, the 2023 deadline to prosecute war crimes cases will not be met. ${ }^{12}$

In relation to the legislation, in dealing with the length and type of punishment, Article 48 of the Criminal Code of Bosnia and Herzegovina, titled General Principles of Meting out Punishments states that:

8 Organization for Security and Co-operation in Europe, Delivering Justice in Bosnia and Herzegovina: An Overview of War Crimes Processing from 2005 to 2010 (19 May 2011), available online at www.osce.org/bih/108103 (accessed 28 February 2021), p. 87.

9 J. Korner, OSCE and British Embassy Sarajevo, Improving War Crimes Processing At The State Level In Bosnia And Herzegovina: A Follow-up Report, available online at www.osce.org/ mission-to-bosnia-and-herzegovina/463728 (accessed 13 March 2021).

10 Organization for Security and Co-operation in Europe, supra note 8, pp. 21-22.

11 Organization for Security and Co-operation in Europe, Observations on the National War Crimes Processing Strategy and its 2018 Draft Revisions, including its relation to the Rules of the Road "Category A" Cases (September 2018), available online at www.osce.org/mission-tobosnia-and-herzegovina/397541 (accessed 19 February 2021), p. 2. 
(1) The court shall impose the punishment within the limits provided by law for that particular offence, having in mind the purpose of punishment and taking into account all the circumstances bearing on the magnitude of punishment (extenuating and aggravating circumstances), and, in particular: the degree of guilt, the motives for perpetrating the offence, the degree of danger or injury to the protected object, the circumstances in which the offence was perpetrated, the past conduct of the perpetrator, his personal situation and his conduct after the perpetration of the criminal offence, as well as other circumstances related to the personality of the perpetrator.

However, leaving these aspects aside, the domestic trials are also visually different from those at the ICTY. The lack of transparency in basic information is probably the greatest challenge. Verdicts are published on the Court of Bosnia and Herzegovina's website. Indictments, briefs, evidence, transcripts are out of reach and only available upon a written request, followed by long delays. The same holds for other data such as photos or video of defendants and court proceedings.

The lack of photographs for example led journalists from BIRN, to recently start taking pictures of defendants on their way to court. These pictures were later used in their new reports. ${ }^{13}$

This 'censorship' is even more pronounced among the local courts in the Federation's cantons and in the Republika Srpska district courts. In order to limit information on war crimes (but also on organized crimes), the Court of Bosnia and Herzegovina in 2012, changed and amended the Rulebook on Gaining Access to Court Information and Cooperation with the Community. Names and surnames of convicted war criminals, their lawyers, the places where the crime have happened, as well as the names of private companies, institutions etc. were changed to initials or replaced with '....'14

This action showed to what extent the judicial institutions were (and still are) under the influence of political actors. Although this decision has since been revoked, after pressure from media and international organizations, a degree of anonymization still exists. This is even more present at the lower courts. Anonymization of verdicts, once painstakingly acquired, provides very

13 For example: N. Džaferagić, 'Koroman: Zarobljenici na Palama umirali od batina', Detektor.ba (14 September 2020), available online at www.detektor.ba/2020/og/14/koroman-zarobljenicina-palama-umirali-od-batina/ (accessed 28 February 2021).

14 'Anonymization 'Threat' to Bosnian Justice Criticised', Justice-Report.com, available online at www.justice-report.com/en/articles/anonymization-threat-to-bosnian-justice-criticised (accessed 28 February 2021). 
little or no usable information going even as far as to erase the date of birth of the defendant.

In a 2019 report, a BIRN investigation uncovered that at least 20 suspected perpetrators had died while awaiting or during trial. ${ }^{15}$ The report highlighted two interesting statements from victim organizations who continue to seek justice for the crimes despite time. For example, the head of the Association of Detainees of Bira Region stated: 'If we consider this from a human aspect, it is horrible to see indictments be imposed on people suffering from serious diseases. On the other hand, another problem is the fact that indictments are filed 25 years after the events of the war. That is absurd.'16 The head of the Association Women Victims of War stated that the authorities are 'buying time so these people will go unpunished'. 'It is obvious that they are waiting for victims, witnesses and war criminals to die.'17

By way of example, during the case Prosecutors' Office of Bosnia and Herzegovina v. Pažin et al. ${ }^{18}$ three out of five defendants died during the course of the trial. ${ }^{19}$ The indictment was issued in 2015 and the first instance verdict was only issued in September 2020. This case is just one illustration of the length of proceedings in relation to group trials. So far, cases involving several defendants proved to be the most complicated and burdensome. The incapability of one defendant usually means the extension of the trial until conditions are met for all defendants to be present.

15 These are: Milan Bogdanović; Jovan Popović; Izet Arifović; Mirko Raguž; Ivica Marković; Cvjetko Popadić; Radivoje Djorđić;Vinko Kondić, Mićo Praštalo; Dragomir Tintor, Zdravko Antonić; Gvozden Lukić: Vlasenica and Milići; Neđad Ćorić: Mostar; Ostoja Balaban; Vlado Stjepanović: Bijeljina; Dragan Lubarda; Fahrudin Hadžiosmanagić-Tadić; Aleksandar Petrović; Fahrudin Alić; Novak Mitrović.

16 H. Rovčanin, 'Bosnian War Crime Cases Halted as Ageing Defendants Die', BIRN (2O December 2019), available online at www.detektor.ba/2019/12/20/bosnian-war-crime-caseshalted-as-ageing-defendants-die/?lang=en (accessed 15 January 2021).

17 Ibid.

18 Court of Bosnia and Herzegovina, Prosecutors' Office of Bosnia and Herzegovina v. Pažin et al, Case no.: S1 1 K 01930315 Kri, available online at www.sudbih.gov.ba/predmet/3482/show (accessed 4 August 2021).

19 E. Dizdarević, 'Another Bosnian Croat Defendant in Stolac Crimes Case Dies', Balkan Insight (16 January 2020), available online at www.balkaninsight.com/2020/o1/16/another-bosniancroat-defendant-in-stolac-crimes-case-dies/ (accessed 19 February 2021). 
The postponement of certain trials, especially those involving highranking officials seem to show foul-play. Izet Baždarević, a former judge and now a lawyer, stated that in regard to trial postponement, medical documentation must be 'serious'. He added that '[p]rocedural actions are sometimes misused, which leads to the postponement of hearings. I was a judge; I know what tricks defendants use.'20

One such case is Prosecutors' Office of Bosnia and Herzegovina v. Borislav Paravac et al. which started in 2016. ${ }^{21}$ This group consisting of highranking political and police officials, included Borislav Paravac former Crisis Committee President ${ }^{22}$ in Doboj and Bosnian Serb Member of Presidency between $2003^{-2006 .{ }^{23}}$ Due to the illness of one defendant Milan Ninković, the trial was postponed until it was finally separated in July $2019 \cdot{ }^{24}$ Ninković's lawyer justified the postponement of the hearings stating that the court is 'obliged to take account of the defendants' health. Nobody can influence the passage of time. There is a problem of the old age of defendants in some cases, but chambers are as efficient as they can be, ${ }^{25}$ The separation proved effective thus far, since the trial continued while Ninkovićs trial, as stated on the Court website 'is currently "dormant" due to the accused person's health situation.'26

The prosecutor in the new case against Ninković asked for an independent evaluation of the defendant's medical status, stating that the medical documentation brought by the defendant was from the Military Medical Hospital in Belgrade, adding that it was difficult to verify it since it is from another country.

20 A. Muslimović, 'Sickness Delays Justice in Bosnian War Crimes Trials', Balkan Insight (12 April 2019), available online at www.balkaninsight.com/2019/04/12/sickness-delays-justicein-bosnian-war-crimes-trials/ (accessed 27 March 2021).

21 Court of Bosnia and Herzegovina, Prosecutors' Office of Bosnia and Herzegovina v. Borislav Paravac et al., Case No.: S1 $1 \mathrm{~K}$ o20503 $16 \mathrm{Kri}$, available online at www.sudbih.gov.ba/ predmet/3528/show (accessed 19 February 2021).

22 The Serb Democratic Party, led by Radovan Karadžić, in 1992 established Crisis Committees in each municipality as a de facto government with the aim of implementing the "cleansing" policy. See D. Erjavec, 'Karadzic Trial: Serb Crisis Committees 'Financed Paramilitaries", Balkan Insight (10 June 2011), available online at www.balkaninsight.com/2011/o6/10/ karadzic-trial-serb-crisis-committees-financed-paramilitaries/.

23 Chronology of the Presidency of BiH, Presidency of Bosnia and Herzegovina, available online at www.predsjednistvobih.ba/hron/default.aspx?id=10074\&langTag=en-US (accessed 19 February 2021).

24 Court of Bosnia and Herzegovina, Prosecutors' Office of Bosnia and Herzegovina v. Ninković Milan, Case No.: S1 1 K 03315719 Kri, available online at www.sudbih.gov.ba/predmet/4034/ show (accessed 19 February 2021).

25 Muslimović, supra note 20.

26 Court of Bosnia and Herzegovina, supra note 24. 
He also recommended trying the case with Paravac et al. Ninković rejected stating,

I am not capable of joining cases, neither physically nor mentally. If you would accept that and something happens to me, then you would be responsible for the possible consequences. ... If you join us together, in my lifetime that subject will not end, and Paravac is even older than me. I have a cardiologist whom I will take with me and he will be there near me. ${ }^{27}$

Similarly, the case of Prosecutors' Office of Bosnia and Herzegovina v. Radenko Stanić et al., which started in February 2018, was also prolonged and is still dormant at the time of writing. The proceedings were initially postponed for several months due to the illness of one defendant Mane Đurić, the former head of the Vlasenica Police Station, who is on trial with other high-ranking political and police officials from Vlasenica. In September 2019, Đurić's case was separated due to his illness. Although the prosecutor's announced the possibilities of re-joining the cases, this has not been done to date. On the other hand, one victim from Vlasenica responded to the court's decision stating: 'By dragging out the proceedings, the court is accommodating our murderers'. ${ }^{28}$ As stated by James Sedgwick, on the trials of post-World War Two Japanese war criminals, 'the aura of fragility turned out to be reality as many escaped justice — or at least reduced their punishments — because of age and other health concerns. ${ }^{29}$

In 2018, 74-year-old Mićo Praštalo, aka Kudra, stopped his car on the road to Lušci Palanka near Sanski Most, took out a hunting rifle and took his own life. ${ }^{30}$ The year before, Prastalo, the former commander of the Sixth Battalion of the Bosnian Serb Army's Sixth Sanski Brigade was arrested and brought before the Court of Bosnia and Herzegovina. He was charged with crimes against humanity against Bosniak and Bosnian Croats in Sanski Most and Ključ in 1992. Bosnian and Croatian media reported briefly about this case.

27 E. Dizdarević,'Ninković sposoban da prati suđenja', Detektor.ba (28 January 2020), available online at www.detektor.ba/2020/o1/28/ninkovic-sposoban-da-prati-sudjenja/ (accessed 20 February 2021).

28 Muslimović, supra note 20.

29 J. Sedgwick, 'An Age-Old Question: Optical (A)llusions, (In)Decency, and (In)Justice in the Trial of Japanese War Criminals', in this issue, pp. 86-107.

30 L. Grebo, 'Bosnian Serb War Crimes Defendant Found Dead', Detektor.ba (22 November 2018), available online at www.detektor.ba/2018/11/22/bosnian-serb-war-crimes-defendantfound-dead/?lang=en (accessed 11 February 2021). 
Croatian website Jutarnji.hr published a story titled 'Accused Killer of Croats Killed Himself: Former Bosnian Serb Army Member Found Dead in Car.31 The news report was referring to the massacre of 68 Bosnian Croats in Briševo village near Prijedor in summer 1992.

A website in Sanski Most, operated by a local Bosniak journalist published a short commentary on Praštalo's suicide. Illustrated with a picture of Praštalo's Volkswagen Golf 2 in which he took his own life, the article was entitled: 'The Puzzle of a Suicide: Did Duke Kudra Kill a Man or a Beast in Himself, or Both?' ${ }^{32}$ The journalist chronicled how after the war Praštalo slowly started befriending Bosniak hunters in Sanski Most. Furthermore, the commentary states how Praštalo had companions among Bosniaks in the town, especially within the Hunting Association, who ignored or minimized his war role. Although he apparently announced that he would never be caught alive, the journalist writes "he survived that "shame", but decided to punish himself, before the State did so on behalf of Kudra's victims after nearly 30 years of waiting.'

The victims' understandable sense of betrayal is becoming increasingly visible. One has the sense that certain suspects and defendants are protected by judicial or political actors prolonging cases awaiting their natural deaths in order to avoid responsibility. One of the Srebrenica mothers, Hajra Ćatić, stated: 'We are witnessing the death of war criminals without serving their sentences, but the punishments they committed in this world remain after their death. ${ }^{33}$ After the death of Vehbija Karić, the Bosnian army general charged with crimes against Croatian civilians in Grabovica, Josip Drežnjak, a representing of the victims stated last year, on the anniversary of the massacre: 'Some were probably just waiting for that moment when he would leave this world. ${ }^{34}$

31 'Ubio se optuženi za stravičan pokolj Hrvata: Bivši pripadnik vojske bosanskih Srba pronađen je mrtav u automobilu', HINA-Jutarnji.hr (22 November 2018), available online at www.jutarnji.hr/vijesti/svijet/ubio-se-optuzeni-za-stravican-pokolj-hrvata-bivsi-pripadnikvojske-bosanskih-srba-pronaden-je-mrtav-u-automobilu-8085665 (accessed 28 February 2021).

32 'Zagonetka jednog samoubistva: Da li je Vojvoda Kudra u sebi ubio Čovjeka ili Zvijer, ili ijedno i drugo?', Normala.ba (22 November 2018), available online at www.normala. ba/2018/11/22/zagonetka-jednog-samoubistva-da-li-je-vojvoda-kudra-u-sebi-ubio-covjekaili-zvijer-ili-ijedno-i-drugo/ (accessed 25 February 2021).

33 'Hajra Ćatić: Ratni zločinci umiru, a ne dočekaju presude za počinjene zločine u Srebrenici', RTV Glas Drine (11 February 2016), available online at www.rtvglasdrine.com/vijesti/hajracatic-ratni-zlocinci-umiru-a-ne-docekaju-presude-za-pocinjene-zlocine-u-srebrenici/ (accessed 20 January 2021).

34 M.K., 'Drežnjak: Nema ništa od istrage zločina u Grabovici, čekaju da svi svjedoci umru', Pogled.ba (9 September 2020), available online at www.m.pogled.ba/clanak/ 
Age, in general, is accepted by the entity level and Brčko District courts across $\mathrm{BiH}$ as, among other things, a mitigating factor. In most cases, these age considerations are made regarding the defendant's age when the offence was committed. ${ }^{35}$ But as rightly recognized by a 2015 OSCE report, 'circumstances accepted in the aggravation and mitigation of a sentence are simply listed, with no detailed discussion as to their impact on the severity of the sentence. This leaves the impression that aggravating and mitigating circumstances are only pro forma listed in judgments.'

The issue of elderly defendants in war crimes cases in $\mathrm{BiH}$ is one that is going to arise frequently in the near future. In my opinion, there are two reasons for this: the majority of the more aged, senior perpetrators, the major political, military and police officials, were dealt with at the ICTY. The domestic courts meanwhile dealt with perpetrators who were mainly direct perpetrators, which meant that these were 'younger' defendants. However, there are a few cases in domestic courts, mainly at the Court of Bosnia and Herzegovina, where elderly defendants were tried and where their age was considered a mitigating factor. Below a short overview of the cases is presented.

The first aged defendant to be tried at the Court of Bosnia and Herzegovina was Marko Samardžija, born in 1936. He was an elementary school history teacher and a well-known and respected member of the local community in Ključ. In July 1992, as commander of the Bosnian Serb Army 3rd Sana Battalion he commanded the attack on Biljani village near Ključ, in which at least 144 Bosniak civilians were massacred. He surrendered voluntarily after Rs Police informed him that the Cantonal Prosecution Office in Bihać had issued an arrest warrant for him in $2005 .{ }^{36} \mathrm{He}$ was 70 years old when, in 2006, he was convicted for crimes against humanity by the Court of Bosnia and Herzegovina. ${ }^{37}$ In its first instance verdict, sentencing him to 26 years imprisonment, the trial chamber stated:

dreznjak-nema-nista-od-istrage-zlocina-u-grabovici-cekaju-da-svi-svjedoci-umru/201627 (accessed 17 March 2021).

35 Organization for Security and Co-operation in Europe, Combating Impunity for ConflictRelated Sexual Violence in BiH: Progress and Challenges (3 April 2014), available online at www.osce.org/bih/117051, p. 37 .

36 'Marko Samardžija se predao', Oslobođenje (19 March 2005), available online at www.infobiro. ba/article/30057 (accessed 19 March 2021).

37 Court of Bosnia and Herzegovina, Prosecutor's Office of Bosnia and Herzegovina v. Marko Samardžija, Trial Verdict, Number: X-KR-05/O7 Sarajevo (3 November 2006), available online at www.sudbih.gov.ba/predmet/2425/show (accessed 23 January 2021). 
So, the Court considered, as mitigating circumstances, the age of the Accused, he is 70, the fact that he is a family man, the fact that he has not violated the law so far, and the fact that his individual criminal responsibility in the perpetration of the said criminal offense consisted of accessory. $^{38}$

The Appeals Chamber, which in 2007 lowered the sentence to seven years, also took into consideration 'the age and health of the Accused. ${ }^{39}$ While awaiting the second instance verdict, in 2007, Samardžija was among the dozen convicted perpetrators who were on hunger strike asking the Bosnian authorities to revoke previous verdicts that had been brought in line with the 2003 Bosnian Criminal Code. The hunger strikers requested that all war crimes sentences passed down be revoked, and retrials held under the SFRY criminal code, which has a lower maximum prison sentence than the $2003 \mathrm{BiH}$ criminal Code. ${ }^{40}$

In the case of Novica Tripković, who agreed to a Plea Agreement, both the Prosecutor and the Defense stated his age and health as a mitigating circumstance. ${ }^{41}$ The Trial Chamber found that 'the fact that the Accused is in the seventh decade of his life, that the expert evaluation found him to be of poor health, and the fact that he is a father of three children and that he behaved properly during the trial' ${ }^{42}$ were mitigating circumstances. He was sentenced to eight years imprisonment for rape and murder in Foča in the summer of 1992.

The same defendant Novica Tripković, was also put on a trial again, this time for war crimes committed in Kalinovik. This trial was conducted together with another defendant, Zoran Bjelica. Again, the Trial Chamber found his age to be a mitigating circumstance, given that he was an 'older and family man

$38 \quad$ Ibid., p. 39.

39 Court of Bosnia and Herzegovina, Prosecutor's Office of Bosnia and Herzegovina v. Marko Samardžija, Appellant Verdict, Case No.: X-KRž-05/O7, Sarajevo (15 October 2008), available online at http://www.sudbih.gov.ba/bundles/websitenews/gallery/predmet/2425/X-KRZ05_07_-_Samardzija_15_10_2008_-_Appellate_Verdict.pdf (accessed 23 January 2021), p. 37.

40 'Indictees "on hunger strike"', Justice-Report (9 January 2009), available online at www. justice-report.com/en/articles/indictees-on-hunger-strike (accessed 23 January 2021).

41 Court of Bosnia and Herzegovina, Prosecutor's Office of Bosnia and Herzegovina v. Novica Tripković, Case No.:S11 Koo241810 Kri (7June 2011), available online at http://www.sudbih.gov. ba/bundles/websitenews/gallery/predmet/2758/2418_1K_TN_prvostupanjska_O7_o6_2011. pdf (accessed 23 January 2021), p. 10.

Ibid., p. 32. 
(married, three children)'43 This was confirmed by the Appeals Chamber: 'the Trial Panel was right in assessing the following circumstances as extenuating circumstances: the accused is an elderly and family person (married, father of three children). ${ }^{44}$

Probably one of the most fascinating cases is that of Veljko Bašić. Bašić was tried along with two other Bosnian Serb perpetrators for crimes committed in Vlasenica in 1992. Bašić, born in 1926, was for a period of time in 1992 commander of the Sušica camp. He was 83 years old when the trial was scheduled to start, making him the oldest defendant brought in front of a domestic court. His defense argued that Bašić was not fit to stand trial. Two doctors assigned by the court found that 'Veljko Basic is not fit to stand trial and attend trial permanently. The defendant is 83 and has serious health problems. ${ }^{45}$ Furthermore, in the trial verdict it was stated that:

the expert-witnesses provided a precise explanation of the results of the expert evaluation and concluded that the person in question is of an advanced old age who, apart from having ..., also suffered from ..., which, in their opinion, is a serious disease with no possibility of recovery or improvement. Based on the presented findings, the expert witnesses are of the view that the Accused Veljko Bašic is not physically or mentally capable of participating in the further course of the proceedings and the Prosecutor therefore moved the Court to separate the proceedings against this Accused.

A few weeks later, the Court rendered a decision to adjourn the proceedings against the Accused Veljko Bašić and refer the Accused to the Centre for Social Work in the territory of the Municipality of Vlasenica, until the conditions

43 Court of Bosnia and Herzegovina, Prosecutors' Office of Bosnia and Herzegovina v. Zoran Bjelica and Novica Tripković, Trial Verdict, Case No.: S1 1 K 01459014 KrI (28 April 2016), available online at http://www.sudbih.gov.ba/bundles/websitenews/gallery/ predmet/3207/14806808031K_o1459o_14_KrI_Bjelica_i_dr_prvostepena_28_04_2016_bos.pdf (accessed 23 January 2021), p. 58.

44 Court of Bosnia and Herzegovina, Prosecutors' Office of Bosnia and Herzegovina v. Zoran Bjelica and Novica Tripković, Appelant Verdict, Case No.: S1 1 K 01459016 Krž (28 November 2016), available online at http://www.sudbih.gov.ba/bundles/websitenews/gallery/ predmet/3207/15040764641K_14590_16_Drugostepena_Bjelica_Zoran_i_dr_28_11_2016.pdf (accessed 23 January 2021), p. 13.

45 'Bastah et al: Basic cannot attend trial', Justice-Report (27 June 2008), available online at www.justice-report.com/en/articles/bastah-et-al-basic-cannot-attend-trial (accessed 28 March 2O21). 
for the continuation of the criminal proceedings against the Accused are satisfied. 46

This court decision was brought in accordance with Article 388 ('Adjournment of the Procedure in Case of a Mental Illness') of the $\mathrm{BiH}$ Criminal Procedure Code, which states that '[i]f the accused becomes affected by such a mental illness after the commission of a criminal offense that he or she is unable to take part in the procedure, the Court shall, upon psychiatric forensic evaluation, adjourn the procedure and send the accused to the body responsible for issues of social care. 47

With that, Bašić was freed and spent the next couple of years of his life in Vlasenica. This created outrage among Bosniak returnees and survivors who stated that he was freed because of his old age, and now they see him in the streets of Vlasenica as a free man. ${ }^{48}$

In several other cases, the age of the defendants was similarly taken into consideration when considering the sentence. In the case of Prosecutor's Office of Bosnia and Herzegovina v. Zoran Babić et al., Milorad Škrbić, born in 1960 and a former reserve police officer of the Prijedor police, was one of the defendants in the Korićanske cliff massacre case. In the trial verdict, the chamber again found his advanced age to be a mitigating circumstance: 'at the moment when the Verdict was pronounced, he was sixty years old so the imposed punishment of long-term imprisonment for him is practically a life sentence. ${ }^{.49}$ However, the Appeals Chamber in its verdict left out his age as a mitigating circumstance without explanation. ${ }^{50}$ Again in the case of Prosecutors' Office

46 Court of Bosnia and Herzegovina, Prosecutors' Office of Bosnia and Herzegovina v. Predrag Bastah et al, Case No.: X-KR-05/122 (4 February 2010), available online at http:// www.sudbih.gov.ba/bundles/websitenews/gallery/predmet/2535/Xo5122_1K_BP_i_dr._ prvostupanjska_04_02_2010.pdf (accessed 15 March 2021), p. 11.

47 Criminal Procedure Code of Bosnia And Herzegovina, (Official Gazette of Bosnia and Herzegovina, 3/o3, 32/o3, 36/o3, 26/o4, 63/04, 13/05, 48/o5, 46/o6, 76/o6, 29/o7, 32/o7, 53/o7, 76/o7, 15/o8, 58/o8, 12/og, 16/og, 93/og, 72/13), available online at www.sudbih.gov.ba/files/ docs/zakoni/en/Criminal_Procedure_Code_of_BH_-_Consolidated_text.pdf. accessed 15 March 2021, p. 73 .

48 S. Karić, 'Povratnicima je teško gledati slobodne zločince', Oslobođenje (22 April 2011), available online at www.infobiro.ba/article/789944 (accessed 15 March 2021).

49 Court of Bosnia and Herzegovina, Prosecutor's Office of Bosnia and Herzegovina v. Zoran Babić et al., Trial Verdict, Case No.: S1 1 Koo3472 og KrI (X-KR-08/549) (21 December 2010), available online at http://www.sudbih.gov.ba/bundles/websitenews/gallery/predmet/2574/3472_1K_ BZ_i_dr._prvostupanjska_21_12_2010.pdf (accessed 15 March 2021), p. 119 .

$5^{\circ}$ Court of Bosnia and Herzegovina, Prosecutor's Office of Bosnia and Herzegovina v. Zoran Babić et al., Appellant Verdict, Case No.: S1 1 K 00347212 Kžk (15 February 2013), available online at http://www.sudbih.gov.ba/bundles/websitenews/gallery/predmet/2574/3472_1K_ BZ_i_dr._drugostupanjska_15_02_2013.pdf (accessed 15 March 2021). 
of Bosnia and Herzegovina v. Krsto Savić and Milko Mučibabić, the trial chamber for Mučibabić cited his age as a mitigating circumstance: 'the Panel has also taken into consideration his age (almost $5^{8}$ years old at the time of pronouncement of the sentence) and his proper conduct throughout the proceedings. ${ }^{51}$ Mučibabić died in 2011 while awaiting a retrial. ${ }^{52}$ Likewise, in the case of Prosecutors' Office of Bosnia and Herzegovina v. Ibro Merkez, the Trial Chamber found Merkez guilty of war crimes and sentenced him to two years imprisonment, stating that the accused was in his 'late life years (born in 1942)'.53 While in the case of Prosecutors' Office of Bosnia and Herzegovina v.Vitomir Račković the Trial Chamber found 65-year old Račković guilty of crimes against humanity and stated as mitigating factors, that the accused was a family man and 'in his late life years. ${ }^{54}$

In Prosecutor's Office of Bosnia and Herzegovina v. Boško Lukić and Marko Adamović the Court of Bosnia and Herzegovina Appeals Chamber found Boško Lukić and Mako Adamović guilty of crimes against humanity against Bosniaks and Bosnian Croats in Ključ, in 1992. In its verdict, the Appeals Chamber found that there were 'no particularly mitigating circumstances on the part of the Accused, except for the fact that these persons are elderly, and have no prior convictions. $^{55}$

Both defendants failed to appear in court for the passing of sentence. Adamović was quickly apprehended, while Lukić, is to this day still at large. ${ }^{56}$

51 Court of Bosnia and Herzegovina, Prosecutors' Office of Bosnia and Herzegovina v. Krsto Savić and Milko Mučibabić, Trial Verdict, Case No.: X-KR-O7/40O (24 March 2009), available online at http://www.sudbih.gov.ba/bundles/websitenews/gallery/predmet/2526/Xo740o_IK_SK_i_ dr._prvostupanjska_24_03_20o9.pdf (accessed 30 March 2021), p. 94.

52 'Milko Mucibabic Dies', Detektor.ba (28 January 2011), available online at www.detektor. ba/2011/o1/28/milko-mucibabic-dies/?lang=en (accessed 30 March 2021).

53 Court of Bosnia and Herzegovina, Prosecutors' Office of Bosnia and Herzegovina v. Ibro Merkez, Trial Verdict, Case No.: S1 1 K 02046616 Kr (25 October 2019), available online at http://www. sudbih.gov.ba/bundles/websitenews/gallery/predmet/3519/15786680311K_20466_16_Kri_ Merkez_Ibro_i_dr_prvostepena_25_10_2019_bos.pdf (accessed 23 January 2021), p. 69 .

54 Court of Bosnia and Herzegovina, Prosecutor's Office of Bosnia and Herzegovina v. Vitomir Račković, Trial Verdict, Case No.: S1 1 K 01436514 Kri (11 May 2015), available online at http://www.sudbih.gov.ba/bundles/websitenews/gallery/predmet/3175/14365_1K_RV_ prvostepena_11_05_2015_bos.pdf (accessed 23 January 2021), pp. 94-95.

55 Court of Bosnia and Herzegovina, Prosecutor's Office of Bosnia and Herzegovina v. Boško Lukić and Marko Adamović, Second Instance Verdict, Case No.: S1 1 K oo3359 12 Kžk (8 November 2013), available online at http://www.sudbih.gov.ba/bundles/websitenews/ gallery/predmet/3285/3359_1K_LB_i_dr._drugostupanjska_08_11_2013.pdf (accessed 30 March 2021), p. 183 .

56 M. Taušan, 'Lukic on the Run, Adamovic Arrested', Detektor.ba (23 December 2013), available online at www.detektor.ba/2013/12/23/lukic-on-the-run-adamovic-arrested/?lang=en (accessed 25 February 2021). 
However, even though Lukić was on the run, the third instance chamber accepted appeals by their defenses and modified their sentences by lowering them. The third-instance chamber found that the Appellate Panel had not taken the defendant's age into consideration, which they found as a mitigating circumstance when defining the sentences. It stated that the time period between the committed crimes and the sentencing needed to be taken into consideration with 'a sufficient weight':

The only exemption is the fact concerning the present age of the Accused, which was not, in the Panel's view, sufficiently taken into account in the meting out of their respective sentences. Specifically, there is no doubt that, at the time of the crime commission, both these Accused were middle-age adults (the Principal-Accused Lukić was around age $5^{2}$, and the Second-Accused Adamović was age 46). However, a total of 22 years elapsed between the critical time and the time of adjudication, so the accused Lukić is now age 74, and the accused Adamović is age 68, which is certainly a significant age in the sentence fixing. It ensues from the challenged Judgment reasoning that the Appellate Panel indeed took into account these facts, but did not give them a sufficient weight. ${ }^{57}$

\section{$5 \quad$ Conclusion}

In December 2019, the Balkan Investigative Reporting Network (BIRN) published a report titled 'Bosnian War Crime Cases Halted as Ageing Defendants $D^{2}{ }^{58}$ in which it found that in the past five years, 20 people indicted for war crimes had died whilst their trials were ongoing. An additional ten cases were halted due to illness of the accused. It is now a quarter of a century since the war has ended, and the fight against time is now two-fold; not only are the suspected and accused persons slowly dying, but so are the witnesses, who are crucial for convictions. This identical report, slightly modified, was published

57 Court of Bosnia and Herzegovina, Prosecutor's Office of Bosnia and Herzegovina v. Boško Lukić and Marko Adamović, Third Instance Judgment, Case No.: S1 1 K oo3359 14 Kž (18 September 2014), available online at http://www.sudbih.gov.ba/bundles/websitenews/ gallery/predmet/3285/14859451343359_1K_Kzz_Marko_Adamovic_i_Bosko_Lukic_ trecestepena_18_09_2014_bos.pdf (accessed 25 February 2021).

58 H. Rovčanin, 'Bosnian War Crime Cases Halted as Ageing Defendants Die', BIRN (20 December 2019), available online at www.detektor.ba/2019/12/20/bosnian-war-crime-caseshalted-as-ageing-defendants-die/?lang=en (accessed 18 February 2021). 
by another news website Faktor.ba under a different title 'Waiting for Victims and Witnesses to Die so that War Criminals Can Stay Unpunished. ${ }^{59}$

This title summarizes the frustration of many survivor and victim groups. Although, as rightly noted by Iva Vukušić, delays are beneficial in certain cases, especially at the ICTY, the victim response is understandable. ${ }^{60}$ The initial frustrations of victim and survivor groups in BiH was with the ICTY and its initial failure to apprehend high-level war criminals such as Radovan Karadžić and Ratko Mladić; the short length of prison sentences; the early releases of convicted war criminals (to name a few). Once the ICTY started its exit strategy and the war crimes trials were picked up by national courts, the criticism shifted from ICTY to the national courts. ${ }^{61}$ Over the past decade, these groups have voiced their criticism and concern, being primarily unhappy with the time needed for certain perpetrators to be apprehended and the length of prison sentence the accused received.

The biological clock of the suspects and witnesses alike is one of the aspects that Judge Joanna Korner warns about in her report: 'Given the ageing of suspects and witnesses as well as the increasing difficulty in obtaining evidence, it will soon not be possible to conduct war crimes trials at all.' ${ }^{62}$ Yet, age as a mitigating circumstance seems to be used by courts without clear jurisprudence. How does one define old age? Or late life years? Certainly, defense lawyers will use the age of their defendants (along with terms such as 'family man') as a tool to receive a lower sentence. In addition, there are also the cases of convicted defendants who are on the run, as well as a significant total of 47 convicted war crimes fugitives who are not in prison. However, it is also visible that the prosecution will continue to pursue suspects of war crimes, even if it means indicting suspects who they cannot physically arrest, as with Nedić.

The purpose of this article was to shed light on the aspect of prosecuting aged defendants at the Court of Bosnia and Herzegovina. It focused on two main aspects: portrayal of the cases in the media and the legal reasoning of the court. As there will be significantly more domestic prosecutions of aged defendants in the time ahead, a separate phenomenon seems to emerge. The impact that media reports have in generating the defendant's aesthetics, a narrative emerges that is to a certain extent, influenced by the perpetrator.

59 'Čeka se da umru žrtve i svjedoci kako bi ratni zločinci ostali nekažnjeni', Faktor.ba (21 December 2019), available online at www.faktor.ba/vijest/ceka-se-da-umru-zrtve-i-svjedocikako-bi-ratni-zlocinci-ostali-nekaznjeni/6336o (accessed 18 March 2021).

6o I. Vukušić, 'Later Rather Than Sooner: Time and Its Effects on the Karadžić and Mladić Trials', in this issue, pp. 188-207.

61 'Strategija okončanja rada MKSJ je potvrđena Rezolucijom 1503 Vijeća sigurnosti UN-a (august 2003. godine) i 1534 (mart 2004. godine)'.

62 Korner, supra note 9 . 